\title{
DRILLING AND COLOR-CODING SYSTEMS: A COMPARATIVE ANALYSIS OF TWO PRONUNCIATION TECHNIQUES TO IMPROVE L2 LEARNERS' PRODUCTION OF THE -(E)D INFLECTIONAL ENDING
}

\author{
Irene Marín Cervantes
}

\begin{abstract}
RESUMEN
El presente estudio analiza la utilidad de la repetición y los códigos de colores para ayudar a un grupo de estudiantes avanzados de inglés a pronunciar el sufijo morfológico -(e)d en las formas verbales regulares del pasado y el participio pasado. Para el estudio, se eligieron tres profesores de ingeniería de la Universidad de Costa Rica. Los resultados indican que la identificación y la pronunciación de los alomorfos /t/ y /d/ presentan mayor dificultad que el alomorfo /Id/. La repetición fue efectiva para identificar las realizaciones de -(e)d; no obstante, ésta no promovió la autonomía de los estudiantes en la producción de los sonidos. El código de colores ayudó a los estudiantes a auto corregirse. Asimismo, el número de errores disminuyó cuando se utilizó dicha técnica. A pesar de las ventajas del código de colores, se concluye que es necesario practicar y reciclar ambas técnicas en la clase para promover el aprendizaje de una segunda lengua.

Palabras clave: repetición, código de colores, técnica, realización, alomorfo.
\end{abstract}

\begin{abstract}
This study analyzes the usefulness of drilling and color-coding systems to help a group of advanced English students pronounce the -(e)d inflectional ending in past and past participial forms of regular verbs. Subjects were three engineering professors working at the University of Costa Rica. After evaluating each technique, results show that the allomorphs /t/ and /d/ were more difficult to identify and pronounce than /Id/. Drilling was effective to identify the realizations, yet it did not promote learner autonomy. The color code was found to help learners self-correct. In addition, the number of mistakes decreased when using this technique. Despite the advantages of the color code over drilling, it was concluded that both techniques need to be practiced and recycled in the classroom to enhance L2 learning.

Key words: drilling, color code, technique, realization, allomorph.
\end{abstract}

Magistra Irene Marín Cervantes.Profesora de Inglés. Escuela de Lenguas Modernas de la Universidad de Costa Rica, San Pedro, San José, Costa Rica.

Correo electrónico: irene.marincervantes@ucr.ac.cr

Recepción: 28- 5- 2009

Aceptación: 23- 6- 2009 


\section{Introduction}

Teaching pronunciation to a group of second language learners is not an easy undertaking. Teachers may find difficulty in trying to help their students at different proficiency levels improve or, at least, to develop an awareness of pronunciation aspects. Contrary to what may be a popular belief, helping advanced students with their pronunciation can be as challenging as teaching pronunciation to beginners. At the advanced level, students have acquired lexis, grammar rules, and strategies. In spite of this, pronunciation is an area that they often want to focus on (Bailey 2005: 142). Usually, pronunciation issues that are commonly taught to highly proficient students go beyond the production of isolated sounds, for instance, the study of suprasegmentals. However, instructors may realize that their advanced students still have problems with specific sounds, e.g., suffixes, and this may discourage one from teaching more complex pronunciation topics. An example of a troublesome sound, even for advanced learners, is the -(e)d inflectional ending present in the past and past participle forms of regular verbs as well as in some adjectival forms.

Despite the fact that satisfactory descriptions of the rules and basic practice are available regarding the -(e)d ending (Celce-Murcia 1996: 252; Avery 1992: 47-48; Hewings \& Goldstein 1998: 122-25), little has been said about ways specifically designed for advanced learners to cope with the pronunciation problems arising from the incorrect application of such inflectional morphemes. Therefore, the area of concern in the present study is the -(e)d inflectional ending in past and past participial forms of regular verbs as pronounced by an ESP (English for Specific Purposes) engineering group of advanced learners. After analyzing the students' needs, it was found that scientific writing was their main need, and speaking about job-related issues their main interest. Certainly, both past forms and past participles, particularly in passive voice constructions, were important for the students not only in terms of writing but also in spoken discourse. Passive voice and past tenses are widely used in scientific writing, which was one of the major focuses of the ESP course for the population in this case.

In order to help students cope with their oral mistakes, the only technique used during the first weeks of the course was immediate error correction after they performed a task. Although this technique worked for a few students, others continued having difficulty in pronouncing the -(e)d ending. Thus, the remedial action taken was the implementation of two techniques to help students improve their production: drilling and the use of a color code system.

\section{Review of the literature}

\subsection{The role of pronunciation in language teaching}

Pronunciation is an area of language learning that goes far beyond the production of phonemes and allophones. It concerns not only physical factors but also affective and social ones since students who experience pronunciation difficulties are affected in terms of their self-image and social identity (Murphy 2003: 112). Pronunciation, then, is a complex but essential skill. It is applicable to what happens inside and outside the classroom and affects the student both as a learner and an individual. According to Dalton \& Seidlhofer (1994: 3 ), pronunciation is significant in two senses: first, as a code system that differentiates one language from another and second, as a means to communicate meaning. 
In spite of the fact that pronunciation is now regarded as an important component of the language class, this has not always been the case. Throughout the history of English language teaching, pronunciation has been assigned a secondary or even tertiary role in the EFL classroom. This partial or total neglect began in early approaches and methods of language teaching. At the start of the nineteenth century, pronunciation fell far behind the teaching of grammar and lexis. During the 1940s and 1950s, an "intuitive-imitative approach" (Celce-Murcia, Brinton \& Goodwin 1996: 2) was followed in which students were supposed to acquire the language, and its pronunciation, by means of listening without any pronunciation training. Pronunciation teaching started to gain relevance later on when methods such as Audiolingualism and the Oral Approach included analyses of sounds and explanations of their production (Murphy 2003: 113). Finally, with the advent of the Communicative Approach in the 1980s, pronunciation was taught in context so that learners could participate in more communicative activities. It is worth mentioning that the Communicative Approach revolutionized language teaching in the sense that it promoted the teaching not only of sounds in isolation as previous approaches had done but also of aspects related to stress, intonation, rhythm, and others (Murphy 2003: 115). From this brief overview of teaching approaches and methods, it is evident that, except for the efforts made by supporters of the Communicative Approach, pronunciation has been characterized by the presence of intuition, imitation, repetition, reception, and passiveness.

\subsection{The nexus between inflectional morphology and pronunciation}

In approaches and methods prior to the Communicative Approach, grammar, lexis, and pronunciation were considered separate areas of language; there was no acknowledgement of their interdependent nature. Therefore, the study of grammar rules was rarely associated with specific pronunciation issues. A case in point is inflectional morphology, which comprises the study of grammatical endings that convey meaning. Grammatical endings, in turn, have been defined as "suffixes that add grammatical information such as tense or number to nouns or verbs" (Avery \& Ehrlich 1992: 47). Inflectional morphology has traditionally been taught as a grammar point detached from its pronunciation rules. One of the most common grammatical endings is -(e)d, which is used with regular verbs in simple past and their past participles as well as in some adjectival forms. Due to the many grammar contexts in which this ending can occur, students are likely to encounter and be obliged to pronounce it often. Interestingly, problems with this particular ending do not arise from its grammar but from the fact that it has three different realizations. Three rules govern the pronunciation of the -(e)d ending in regular verbs: -(e)d is pronounced /d/ if the verb ends in a vowel or voiced consonant, $/ \mathrm{t} / \mathrm{if}$ it ends in a voiceless consonant, and $/ \mathrm{Id} /$ if it ends in $/ \mathrm{t} / \mathrm{or} / \mathrm{d} /$.

The reasons why this inflectional ending poses difficulty for learners have been a concern in previous research. Browne \& Huckin (1987: 49) refer to a lack of sound-spelling correspondence. Students write -(e)d, and that is exactly the way they pronounce the ending. Other authors have described the same phenomenon by saying that the problem consists of an unnecessary insertion of an epenthetic vowel, particularly /o/ (Kelly 2000: 125). As a result, English learners pronounce this extra vowel in all instances of -(e)d. Moreover, students tend to overgeneralize the pronunciation of -(e)d as /əd/, probably because they first study the grammar rule of attaching -(e)d to all regular verbs. Thus, it is difficult for them to disregard such a fixed rule to pronounce the three realizations of the ending (Kelly 2000: 125). Still, other researchers 
have emphasized that final consonant clusters represent the major difficulty for students in the case of /t/ and /d/ (Celce-Murcia, Brinton \& Goodwin 1996: 255). According to Avery \& Ehrlich (1992: 152), Spanish speakers, in particular, have difficulty because final clustering is uncommon in their L1.

\subsection{Techniques used to learn the pronunciation of inflectional endings}

In order to help learners cope with the different realizations of -(e)d, a repertoire of techniques that derived from many of the approaches and methods mentioned earlier is available. In the words of Anthony (1963), as cited in Richards \& Rodgers (2001: 19), a technique is "implementational - that which actually takes place in a classroom (...)"; in addition, techniques must be "consistent with a method" (ibid: 19). One of the most traditional techniques used in pronunciation is drilling, which consists, in its most basic form, of having the students repeat after the teacher. Drilling is commonly linked to Audiolingualism, a method from the 19401950s in which pronunciation gained relevance through teachers' explanation of phonetics, use of transcriptions, and modeling (Celce-Murcia, Brinton \& Goodwin 1996: 3). Drilling can be implemented with the whole class in unison or with specific students. The former allows students to feel more confident since everyone is repeating simultaneously; the latter enables the instructor to monitor the production of individual students (Kelly 2000: 16). Furthermore, this technique is teacher-centered since the instructor has a controlling role, providing an appropriate model for the students to imitate. Proper drilling has been considered a desirable teaching skill which can help learners improve and remember pronunciation rules (Kelly 2000: 16). Nevertheless, drills have been criticized because they represent one of the most controlled pronunciation practices. Its repetitive nature and lack of creativity have made of drilling a technique that teachers do not want to use for long periods of time (Harmer 1991: 92).

Contrary to drilling, other pronunciation techniques are less controlled. Among these techniques, the use of "visual reinforcement" (Celce-Murcia, Brinton \& Goodwin 1996: 295) stands out. Visual reinforcement may include several devices serving the purpose of cuing sound production, for example, the use of colors to represent specific sounds. Although the use of colors can be part of any language method, it has been frequently associated with the Silent Way, a method from the 1970s. The Silent Way paid attention to pronunciation as Audiolingualism did; it dealt with the production not only of individual sounds but also of suprasegmentals. It has been argued that the difference between Audiolingualism and the Silent Way is that the latter does not require learners to study a phonetic alphabet or process explicit linguistic data in order to learn the sound system (Celce-Murcia, Brinton \& Goodwin 1996: 5). Little has been said about using colors for teaching the pronunciation of inflectional endings. However, it has been argued that color code systems, color rods, and charts like those in the Silent Way can be used "to visually demonstrate intonation patterns and to indicate different pronunciations of morphological endings" (Celce-Murcia, Brinton \& Goodwin 1996: 6). Most of these devices used a color-coding system; for instance, colors were consistent in wall charts for the students to distinguish between vowels and consonants. Beyond substituting sounds for a particular color, the use of color codes in the Silent Way gained significance because it equipped learners with a tool they could resort to on their own (Stevick 1998: 129) without extreme teacher intervention. Moreover, the use of color-coding systems may help learners to be autonomous since they know when and how to pronounce a 
sound based on its color. Thus, this use of colors will actually become part of the data stored in learners' memory (Stevick 1998: 129).

The pronunciation of the -(e)d inflectional ending is not an easy topic to teach nor to learn. However, once students have learned the grammar rule, teachers can implement techniques such as drilling or the use of color-coding systems to help their students cope with this pronunciation issue. From the previous review, it can be argued that the ending might be troublesome for Spanish speakers and, therefore, will need recycling. Nonetheless, drilling and the use of a color code are two techniques that can serve this purpose effectively. Indeed, learners require several encounters and time to get used to a color code system in order to associate sounds with a particular color.

\section{Research questions}

The present study sought to answer the following research questions:

1. According to a group of advanced English students in an ESP engineering course, which technique, drilling or the use of a color code system, proves to be more useful in helping them correctly produce -(e)d in past and past participial forms of regular verbs?

2. Does students' production of $/ \mathrm{t} /, / \mathrm{d} /$, and $/ \mathrm{Id} /$ improve after the implementation of such techniques?

\section{Context and Participants}

The participants of this study were three students taking a four-month ESP course designed for engineers at the University of Costa Rica. Two of them are experts in agricultural engineering, and the third is a mechanical engineer. The three subjects are professors at the aforementioned university. Their level of proficiency ranged from high intermediate to advanced, as revealed in a needs analysis carried out prior to the teaching of the course.

The needs analysis showed that the learners' areas of interest were writing and speaking skills, specifically writing academic articles for national and international publication, as well as speaking about job-related topics. The course was offered twice a week in two-hour sessions, and it followed the principles of the task-based approach; therefore, each lesson was structured in terms of a warm-up, pre-, main, and post-task.

\section{Procedure}

Two techniques were selected to help subjects improve the pronunciation of -(e)d: drilling and the use of a color code system. Drilling consisted of group and individual student repetition after the instructor. In the case of the color code system, colored cards were shown for the students to remember the realization that each color represented. In order to obtain a more reliable comparison of both techniques, each realization was practiced twice, using a different technique each time. In addition, to avoid biased results, the techniques were not implemented following a particular order. Once both techniques were introduced, seven different activities were designed to practice -(e)d. The activities varied in terms of length of time and stage of application; i.e., four of them were part of the warm-up, one part of the pretask, and two part of the post-task. 
Different groupings and elicitation techniques were used to evaluate subjects' production. For instance, the three subjects were asked to work as a group for the instructor to monitor their pronunciation; they were also called on to participate in the activities. When the subjects were assigned to separate groups, the instructor and an assistant monitored their work. The implementation process followed five steps, which were repeated every time a different realization was practiced: introduction/review of the realization, introduction/review of the technique, practice, monitoring, and feedback. The /t/ realization had to be practiced three times because of subjects' absenteeism the first time it was introduced.

\section{Instruments}

For the purposes of collecting data, three instruments were designed. First, an oral exam was used as a pre-test to determine if there was a tendency on the subjects' part to mispronounce one of the -(e)d realizations in particular. The same exam was used as a posttest with the aim of determining the level of improvement, if any, in subjects' production. The test consisted of a three-paragraph reading about the topic of biofuels. It included 17 regular verbs. This instrument was accompanied by a set of instructions that asked subjects not to stop while reading the text even if they encountered an unfamiliar word (Appendix 1). Students' performance during the pre- and post-tests was recorded on tape for further analysis.

Second, a questionnaire was administered via email since this was found to be the most efficient way of communication (Appendix 2). The questionnaire was sent six times to the subjects that attended those classes in which the techniques were implemented. The objectives of this instrument were to find out the degree of usefulness of both drilling and the color code system, and to identify the ways in which these techniques were helpful for the subjects. Third, a checklist was filled out during six consecutive lessons (Appendix 3). This checklist helped monitor students' use of drilling and the color code and aided in identifying mistakes that subjects made even after the implementation of the techniques.

\section{Materials}

Seven activities were designed to practice -(e)d using the two techniques. These activities revolved around the topics of the global food crisis and food storage systems, which were being studied in the course at that moment. The following is a description of each activity with the corresponding /t/, /d/, or /Id/ suffix realization practiced and the technique implemented.

\subsection{Drilling}

1. Information gap activity. In pairs, students transformed sentences into the passive voice and shared them out loud with their partners. All -(e)d endings in the passive voice were realized as $/ \mathrm{t} /$. The students repeated the verbs after the instructor. Later, subjects repeated one of the verbs individually (Appendix 4).

2. Brainstorming activity. In groups, students wrote down as many verbs in -(e)d form realized as /d/ as they could. Each member contributed one verb and passed the handout to the person on his right. Students read the verbs they wrote aloud, and subjects were asked to repeat one of these verbs (Appendix 5). 
3. Identification exercise. Individually, students read the methodology section of a research article and identified -(e)d suffixes realized as /Id/. Volunteers read the verbs found aloud. After a verb was mentioned, the instructor asked a different subject to repeat it to the class (Appendix 6).

\subsection{Color-coding system}

The color-coding system consisted of three colors: blue stood for $/ \mathrm{t} /$, orange for $/ \mathrm{d} /$, and green for $/ \mathrm{Id} /$. In cases of mispronunciation, the instructor showed the corresponding color card to help subjects self-correct in all of the following activities.

1. Association exercise. Students were shown blue, orange, and green pieces of candy and were asked to take some. The number of pieces of candy indicated the number of sentences the student had to generate for the class. Colors indicated the ending required. Emphasis was put on /t/ production.

2. Memory game. A grid with twelve pairs of regular verbs in -(e)d form was posted on the classroom board. The / $\mathrm{t} /$ ending was emphasized. Students took turns uncovering the squares and trying to find pairs of verbs. After a square was uncovered, the student pronounced the verb for the class. When a student found a pair of verbs, he had to provide a sentence including said verb.

3. Information gap activity. In pairs, students asked questions to complete a chart with verbs in -(e)d form. The ending of each verb was highlighted according to its pronunciation; the /d/ realization was emphasized. At the end, the instructor called on subjects to provide the answers (Appendix 7).

4. Pieces of color paper. Students took as many pieces of paper as they wanted from a bag. The number indicated how many sentences the student had to provide; colors indicated the ending needed. Green pieces of paper outnumbered those of other colors because the emphasis of the activity was on /Id/ production.

\section{Results}

The results of the present study will be divided into two sections. First, subjects' performance, prior to and after the oral test, will be compared. Second, aspects regarding the implementation and usefulness of the two techniques will be reported.

\subsection{Pre- and post-tests}

Figure 1 shows the cases of omission, mispronunciation, and correct realization of -(e)d in the subjects' performance during the pre-test. In the case of subjects \#1 and \#2, data reveal that the main problem was omission; i.e., the deletion of the ending. Contrary to what was expected, instances of mispronunciation (incorrect selection of a realization) were few compared to those of omission, with the exception of subject \#3, who had an equal number of omissions and mispronunciations. Interestingly, cases of correct realizations outnumbered the ones of omission and mispronunciation in the performance of subjects \#2 and \#3. 


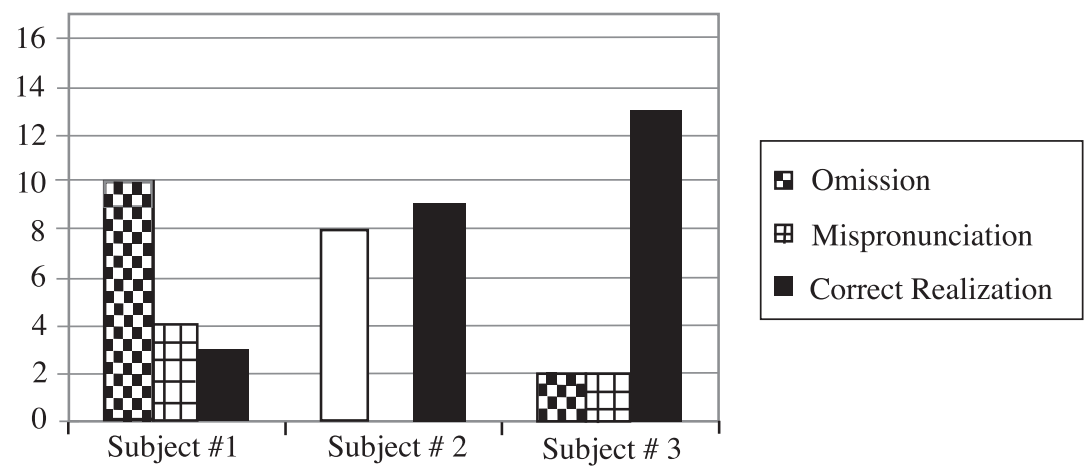

Figure 1. Subjects' performance in the pre-test

Regarding subject \#1, out of 6 endings realized as /t/, 2 were incorrectly pronounced as $/ \mathrm{Id} /$, and the ending was omitted in the remaining 4 cases. Similar results were obtained in the case of $/ \mathrm{d} /$. Out of 6 endings, 2 were realized as $/ \mathrm{Id} /$, and the ending was omitted in 4 instances. The production of $/ \mathrm{Id} /$ was the least problematic for subject \#1, with 3 verbs being pronounced correctly out of 5. The remaining 2 endings were omitted. Subject \#2 omitted the pronunciation of the allomorph /t/ in 5 verbs out of a total of 6 . The remaining ending was accurately realized as /t/. With respect to the $6 / \mathrm{d} /$ endings, 3 were realized correctly, whereas 3 were omitted. All /Id/ endings were pronounced correctly. On the other hand, subject \#3 produced 4 /t/ endings accurately out of a total of 6 . The other two endings were incorrectly pronounced as $/ \mathrm{d} /$ and $/ \mathrm{Id} /$ respectively. Out of 6 endings realized as $/ \mathrm{d} /, 4$ had the correct pronunciation while the ending was omitted in the remaining 2 instances. Subject \#3 pronounced /Id/ correctly in all verbs that required it. Table 1 presents the number of omissions, mispronunciations, and correct realizations per allomorph. As can be seen in the table, the most problematic sounds were $/ \mathrm{t} /$ and $/ \mathrm{d} /$, /Id/ being the least troublesome for all subjects.

Table 1. Omission, mispronunciation, and correct realization in the pre-test

\begin{tabular}{lccc} 
& \multicolumn{1}{c}{$/ \mathbf{t} /$} & /d/ & /Id/ \\
\hline \multirow{2}{*}{ Subject \#1 } & O: 4 & O: 4 & O: 2 \\
& M: 2 & M: 2 & M: 0 \\
& CR: 0 & CR: 0 & CR: 3 \\
& & & \\
Subject \#2 & O: 5 & O: 3 & O: 0 \\
& M: 0 & M: 0 & M: 0 \\
& CR: 1 & CR: 3 & CR: 5 \\
& & & \\
Subject \#3 & O: 0 & O: 2 & O: 0 \\
& M: 2 & M: 0 & M: 0 \\
& CR: 4 & CR: 4 & CR: 5 \\
\hline O: omission & & & \\
M: mispronunciation & & & \\
CR: correct realization & & &
\end{tabular}


In regard to the post-test, results show that the number of omissions decreased for the three subjects. All subjects had mispronunciation problems; indeed, this was the most serious mistake in the performance of subject \#1. In addition, the number of correct realizations increased considerably in the three cases (See Figure 2).

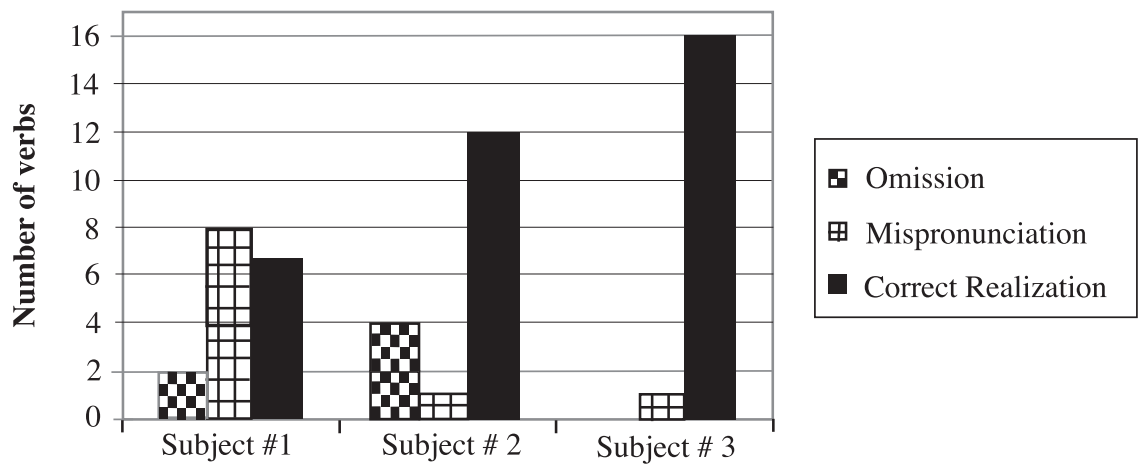

Figure 2. Subjects' performance in the post-test

Subject \#1 pronounced /t/ correctly only once out of a total of 6 cases; 5 endings were mispronounced as $/ \mathrm{Id} /$. On the other hand, out of $6 / \mathrm{d} /$ endings, 3 were wrongly pronounced as $/ \mathrm{Id} /$, and the ending was omitted in two instances. The remaining ending was pronounced correctly. All 5 endings realized as /Id/ were pronounced correctly. Subject \#2's /t/ production resulted in 1 case of omission, 1 of mispronunciation, and 4 of correct realization. Regarding /d/, the ending was pronounced correctly 4 times and omitted twice. Out of $5 / \mathrm{Id} /$ endings, 4 were pronounced appropriately, yet the ending was omitted once. In contrast to subjects \#1 and \#2, subject \#3 did not omit any endings in the post-test. Out of $6 / t /$ endings, subject \#3 pronounced 5 correctly; the other ending was mispronounced as $/ \mathrm{d} /$. In the case of $/ \mathrm{d} /$ and $/ \mathrm{Id} /$, all endings were pronounced correctly. Table 2 presents the specific number of omissions, mispronunciations, and correct realizations per allomorph. As was the case in the pre-test, the most difficult realizations for the subjects were $/ \mathrm{t} /$ and $/ \mathrm{d} / \mathrm{/} / \mathrm{Id} /$ being the least problematic sound.

Table 2. Omission, mispronunciation, and correct realization in the post-test

\begin{tabular}{lccc} 
& \multicolumn{1}{c}{$/ \mathbf{t} /$} & /d/ & /Id/ \\
\hline Subject \#1 & O: 0 & O: 2 & O: 0 \\
& M: 5 & M: 3 & M: 0 \\
CR: 1 & CR: 1 & CR: 5 \\
Subject \#2 & O: 1 & O: 2 & O: 1 \\
& M: 1 & M: 0 & M: 0 \\
Subject \#3 & CR: 4 & CR: 4 & CR: 4 \\
& O: 0 & O: 0 & O: 0 \\
& M: 1 & M: 0 & M: 0 \\
& CR: 5 & CR: 6 & CR: 5 \\
\hline
\end{tabular}

$\mathrm{O}$ : omission

M: mispronunciation

CR: correct realization 


\subsection{The techniques}

With respect to the use of the techniques, the subjects never asked how any of them worked. Instead, subjects posed questions related to the pronunciation of certain verbs or about the instructions for the activities. In the three sessions in which the color code was used, subjects were enthusiastic; they enjoyed the activities and monitored themselves. In the case of the three sessions with drilling, subjects also showed interest by repeating after the instructor and volunteering to repeat verbs individually.

The techniques were evaluated in terms of how appropriately students used them. Subjects had some difficulty using the color code. The reason for this was the incorrect association of a color with its corresponding allomorph. Subject \#3 mispronounced the verb used as /yuwzəd/ in spite of the presence of the orange color that represented /d/. Out of three classes where drilling was practiced, subjects failed to use the technique just once. This happened the first time that the technique was implemented because the students did not understand the instructions, and therefore, did not repeat after the instructor but only listened to her.

Subjects made mistakes related to the pronunciation of $/ \mathrm{t} / \mathrm{d} / \mathrm{d} /$, and $/ \mathrm{Id} /$ in the five sessions when monitoring was feasible. In the remaining lesson, the activity was part of a posttask; hence, there was not enough time to monitor students' production. In the three classes where the color code was used, subjects mispronounced -(e)d eleven times. On the other hand, eighteen mistakes were made when using drilling; eleven were cases of mispronunciation, and the other seven were omissions. The most problematic verbs during the observations were those ending in /t/ such as asked and produced. Second, verbs ending in /d/, particularly those whose last sound was a voiced sibilant fricative, for instance, caused, raised, and used, presented difficulty. Again, verbs ending in /Id/ were the least problematic.

\subsubsection{Drilling}

Out of six questionnaires assessing drilling, this technique was described as easy to understand five times, useful four times, and interesting two times. Furthermore, none of the subjects considered this technique difficult; indeed, they mentioned that the technique was "a little difficult" five times and "not difficult" once. The subjects reported that the technique was easy to understand and to follow. It was also mentioned that drilling encouraged students to practice what they had learned in the classroom and that listening to the teacher's modeling and repeating after her had improved the production of the ending. More importantly, one subject indicated that repetition was quite natural. Another subject said that drilling was easy because teacher modeling of the sound was available. One subject considered it difficult since the time allowed for repetition was sometimes very limited, and the pronunciation of the ending was rushed. Figure 3 shows the usefulness of drilling as a technique to improve the pronunciation of the ending.

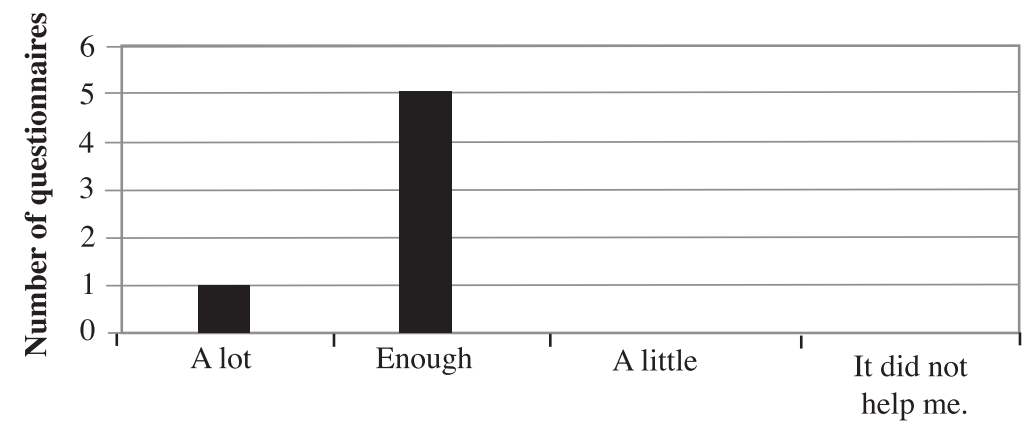

Figure 3. How much did drilling help you pronounce -(e)d endings correctly? 
Drilling helped students in different ways. One of the subjects said this technique was useful to understand how to pronounce -(e)d, to practice what was learned in the course, and to force him to produce the ending. Another subject pointed out how drilling was useful to distinguish /t/ in particular, as well as to learn the pronunciation of /Id/ because the subject was uncertain about it. The other subject said drilling helped him distinguish verbs ending in /Id/ and pronounce them correctly. Subjects were also required to assess the usefulness of drilling by stating whether it would help them remember the pronunciation of $-(e) d$ in the future. Two subjects concurred in the belief that more practice was needed to develop the habit of producing the endings; therefore, more out-of-class time was necessary. One subject mentioned that the technique per se would not be helpful to remember the pronunciation of the ending, but that it was a good way to learn how to pronounce the sounds.

Students were also asked to assess their improvement after the technique was used. In the case of / $t$ /, two students said drilling had helped them improve their pronunciation because of two reasons. First, the technique is common in the acquisition of any L1. Second, after using drilling, students had a clearer idea of what final sounds require /t/. Regarding /d/, one student said his pronunciation had improved, yet no explanation was provided. In the case of /Id/, the three subjects agreed that they had improved after using drilling because it emphasized the correct pronunciation of the sound; in addition, repeating the variant several times in class was effective. One subject wrote that drilling was helpful to improve /Id/ production because the vowel + consonant combination is similar to the type of sounds that exist in Spanish, as opposed to consonant clusters. Regardless of the realization, all subjects concurred that more practice in and out-of-class should be provided.

\subsubsection{Color-coding system}

This technique was evaluated very positively since it was described as easy to understand six times, useful five times, and interesting five times. In terms of difficulty, the technique was considered "a little difficult" six times and "not difficult" once. Subjects said the low level of difficulty was partly due to the fact that the technique made it possible to both identify the sounds and associate the colors with /t/, /d/, and /Id/ more easily, helped them to remember the correct pronunciation, was simple and easy to understand, encouraged subjects to look for the correct pronunciation, and allowed students not only to remember but also to apply pronunciation rules correctly. Moreover, one subject mentioned that the technique was easy because visual aids facilitated his learning, unlike charts or lists of verbs and phonetic symbols. Another subject stated that it was important to accompany the color-sound association with the rule for pronouncing the three allomorphs. As can be seen in Figure 4, a wider variety of answers was obtained regarding the usefulness of the color code system.

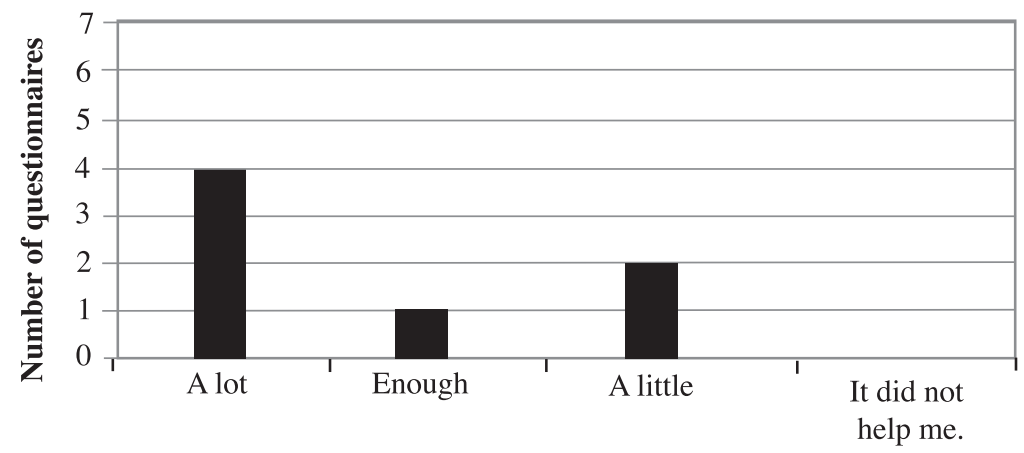

Figure 4. How much did the color code system help you pronounce -(e)d endings correctly? 
Two subjects said the technique was useful because it was a different way to study the pronunciation of regular verbs in past form. Two subjects mentioned that the technique helped because it was well-designed and implemented; it was also applicable, practical, fast, efficient, and easy to use in the classroom. Another subject stated that associating a color with an ending was simple; however, the rules for -(e)d pronunciation would always be needed. When asked if the color code system would help them remember -(e)d pronunciation in the future, answers varied. Two subjects said that the colors would remind them of verbs ending in voiceless and voiced sounds and would stimulate visual and auditory memory. Interestingly, one subject said that the color code would be useful to remember neither $/ \mathrm{t} / \mathrm{nor} / \mathrm{d} / \mathrm{realizations}$. This subject stated that repetition was more effective than using colors although the latter offered autonomy. In fact, this student suggested including repetition prior to the use of colors. In contrast, this same subject said the use of colors would be helpful to remember /Id/ since the instances in which it occurred were easier to identify.

On the topic of improvement, two students considered that the color code system helped them pronounce / $/$ / correctly because there was constant practice of the ending in class. In the case of /d/, the implementation of the technique had a specific advantage for two subjects. It drew students' attention not only to the production of /d/ but also to the recognition of the final voiced sounds that require this allomorph, for instance, /r/, /z/, or /aw/. One of the subjects stated that the color code did not help him improve because more practice was needed in order to produce the ending. In the case of /Id/, two subjects agreed that the color code was effective to improve their pronunciation. One of these subjects emphasized that /Id/ was the easiest sound to identify and produce. The three subjects coincided in that more pronunciation exercises are needed.

\section{Discussion and conclusions}

The first research question addressed in this paper was which technique, drilling or the color code system, was perceived by the students as the most useful to improve their production of -(e)d. Based on the findings, it can be argued that both techniques are useful and should be implemented in a complementary fashion. Nonetheless, the color code seems to be slightly more useful than drilling. Data suggest that the use of colors stimulated memory because the students were able to match the colors with each ending in most of the activities done, and they used these colors to remember -(e)d pronunciation. Colors helped students self-correct when making a mistake, which was not the case with the use of drilling. More importantly, the number of errors made by students decreased in classes where the color code system was used, which clearly indicates that this technique tended to be more useful for the students.

Additionally, using a color code system had the advantage of encouraging students to produce the sounds on their own without the help of the teacher. Results also show that the color code was effective to some extent when detecting voicing, or the lack thereof. Another evident advantage of the color code system was that it empowered learners to self-correct. Drilling requires teachers to point out the mispronounced verb for the students to repeat after them. Conversely, when the color code was used, students had to look at the corresponding color of the mispronounced ending and correct themselves at once. 
On the other hand, drilling was found to be a natural process that occurs in L1 acquisition; therefore, students were able to transfer this information to the L2. This is important since students do not consider the technique difficult because they are already familiar with it. Moreover, drilling had the advantage of forcing students to practice pronunciation because they need to repeat before they go on with the activity. One of the most important conclusions regarding drilling is that it is useful to clarify the difference in pronunciation of $/ \mathrm{t} / \mathrm{d} / \mathrm{d} /$, and /Id/ and that it helps students distinguish final sounds preceding those allomorphs. However, this implies that drilling only enables students to identify the correct ending. It does not help learners progress from the identification to the application stage.

Data also indicate that drilling has two flaws. First, it was said that the technique was easy because teacher modeling of the sound was available. Although having a model may be positive in some contexts, it obviously does not promote learner autonomy because students need a model to be able to produce the ending correctly. This suggests that learners might mispronounce the ending in the absence of a model, i.e., the teacher. Second, the higher number of errors made in classes using drilling supports previous research indicating that repetition guarantees neither the acquisition nor the accurate pronunciation of a language point regardless of the number of times in which repetition might be used. It was also discovered that drilling, as well as the use of the color code system, did not contribute to the correct pronunciation of $/ \mathrm{Id} /$ in particular. What made the pronunciation of this realization easy was the presence of a vowel before the consonant, which is more similar to Spanish sound sequences. Other important conclusions drawn from this study are that both techniques need to be practiced and recycled often for the students to be able to produce -(e)d more naturally. Practice will ensure students' exposure to different examples of regular verbs. It can also be concluded that despite the usefulness of the techniques, students need to be reminded of the rule for the -(e)d suffix pronunciation both orally and in written form.

The second research question of this study was whether drilling and the color code system helped students improve their -(e)d production. According to the data gathered in pre- and post-tests, the techniques did help students improve their pronunciation. However, the slight increase in cases of mispronunciation in post-tests indicates that students still need to carry out practice in which the sounds are recycled. This practice should focus on distinguishing voicing in final sounds since this seems to be the root of mispronunciation cases. On the other hand, omissions are usually the product of lack of awareness. Accordingly, the decrease in omissions in post-tests suggests that the implementation of both techniques raised students' awareness of the rules involved. In regard to the realizations, the order of difficulty for most subjects is /t/ and /d/ respectively. / Id/ caused the least difficulty. This might be explained by the fact that /Id/ is a separate syllable, which makes it not only easier to pronounce but also more salient. Hence, consonant clusters ending in voiceless sounds, for instance, the verb reduced/rə'dyuwst/, are more challenging.

As a final remark, including the color code system in the English class in addition to traditional drilling is important to the ultimate objective of helping students improve -(e)d production. Although it takes time because students need to get used to the colors and their meaning, it is worth teaching so that learners not only recognize but also use -(e)d correctly. 


\section{Limitations}

During the present study, the following three limitations were encountered.

1. Subject absenteeism hindered the data collection process. One of the instruments for gathering information could not be applied as planned because two of the subjects were absent, and the one who attended class came when the activity designed to practice -(e)d was about to conclude. In addition, not all subjects attended the classes in which the ending was practiced; therefore, loss of data was inevitable. Attendance problems also led to the creation of seven activities although only six were originally planned. The extra activity was used with the color code system. This might have biased the results obtained for this technique.

2. Using e-mail to send and answer questionnaires did not guarantee anonymity in the responses. However, the information collected through this means served the purpose of more carefully focusing on the subjects' opinions about the use of the techniques.

3. The second question on the observation checklist proved to be ineffective. Assessment of students' attitude towards the two techniques was based merely on the subjective appraisal of the instructor. As a result, the data obtained in this section was not valid to arrive at a conclusion regarding students' interest in the techniques.

\section{Recommendations}

In order to assess the effectiveness of pronunciation techniques, all activities should be part of the warm-up or pre-task stages of the lesson. In this way, instructors have more opportunities to monitor their students' use of the techniques and their pronunciation. Also, since the spelling of some verbs can be misleading, it is also recommended that instructors highlight exceptions, i.e., verbs such as use, which changes its final sound depending on its grammatical category: /yuws/ $\rightarrow$ noun, /yuwz/ $\rightarrow$ verb. This clarification, prior to the use of the techniques, will help learners understand the concept of voicing, focus on the importance of final sounds preceding -(e)d, and avoid possible sources of confusion. Finally, researchers who want to analyze students' attitudes should establish a set of parameters to evaluate this aspect in order to avoid gathering subjective data.

\section{References}

Avery, Peter. \& Susan Ehrlich. 1992. Teaching American English pronunciation. New York: Oxford University Press.

Bailey, Kathleen. 2005. Practical English language teaching: Speaking. New York: McGraw Hill.

Browne, Sandra \& Thomas Huckin. 1987. "Pronunciation tutorials for nonnative technical professionals: A program description.” In: Morley (ed.), 41-58. 
Celce-Murcia, Marianne, Donna Brinton \& Janet Goodwin. 1996. Teaching Pronunciation: A Reference for Teachers of English to Speakers of Other Languages. New York: Cambridge University Press.

Dalton, Christine \& Barbara Seidlhofer. 1994. Pronunciation. New York: Oxford University Press.

Harmer, Jeremy. 1991. The Practice of English Language Teaching. New York: Longman.

Hewings, Martin \& Sharon Goldstein. 1998. Pronunciation plus: Practice through interaction. New York: Cambridge University Press.

Kelly, Gerard. 2000. How to teach pronunciation. Essex: Longman.

Morley, Joan (ed.). 1987. Current perspectives on pronunciation. Washington: TESOL.

Murphy, John. 2003. "Pronunciation.” In: Nunan (ed.), 111-128.

Nunan, David. 2003. Practical English language teaching. New York: McGraw Hill.

Richards, Jack \& Theodore Rodgers. 2001. Approaches and methods in language teaching. New York: Cambridge University Press.

Stevick, Earl. 1998. Working with teaching methods: What's at stake? Toronto: Heinle \& Heinle. 


\section{Appendix 1}

\section{Oral Reading Test}

The following reading is part of an action research project to be conducted during the English course you are taking. Its purpose is not to make judgments about your oral skills; instead, the information obtained will be very valuable for developing the project.

\section{Instructions:}

1. Read the text below aloud including its title.

2. Use your normal speaking pace.

3. Do not stop to ask questions about vocabulary; ask them before or after reading.

4. Do not worry if you do not know the pronunciation of a word; say it as it comes out.

\section{Some Considerations about Biofuels}

Due to the increasing prices of fossil fuel worldwide, biofuels emerged as a possible future alternative to deal with the changing oil market. Biofuels are transportation fuels that are obtained from biomass materials.

These fuels are usually blended with the petroleum fuels, but they can also be used on their own. Currently, biofuels are produced from conventional food crops such as wheat, sugar, and soy. Biofuels from such crops have created a direct competition with their use for food and animal feed, and in some parts of the world, the economic consequences of such competition are evident. Future biofuels are likely to be produced from a much broader range of feedstocks including grasses and vegetable waste.

The pros and cons of biofuels have been widely researched, and different studies have been conducted to determine their economic and environmental impacts. Specially, laboratory tests are trying to show if greenhouse gas emissions can be reduced by using biofuels. In spite of all the controversies that surround the development of biofuels, they are one component of the newly emerging knowledge-based bio-economy. Society has started to recognize the opportunities offered by such a bio-economy.

Part of the excitement about biofuels comes from the fact that they are considered at first sight to be carbonneutral, renewable, and that plants can be cultivated in many different environments. The truth, of course, is more complex; one biofuel is not the same as another and each must be considered against sustainability criteria. Indeed, each biofuel must be assessed individually. This assessment should include a generic set of parameters such as environmental, socio-economic, political and regulatory issues. 


\section{Appendix 2}

\section{Cuestionario para el estudiante $\ominus$ Técnica-Repetición/Código de Colores}

\section{Sobre la técnica}

1. ¿Qué le pareció esta técnica? De los siguientes adjetivos, marque con una equis $(\mathrm{X})$ los que considera que mejor describen la técnica. Puede seleccionar más de una opción.
$\square$ aburrida
$\square$ interesante
$\square$ útil
$\square$ ineficaz
$\square$ fácil de entender
$\square$ confusa

2. ¿Le resultó difícil utilizar esta técnica? $\square$ Sí $\square$ No

3. ¿Qué tan difícil fue la técnica para usted?

$\square$ muy difícil $\square$ bastante difícil $\square$ poco difícil $\quad \square$ nada difícil

¿Por qué?

\section{Sobre el estudiante}

1. ¿Considera que su pronunciación de los sonidos /t/, /d/ y /Id/ ha mejorado después de utilizar esta técnica? ¿Por qué? ¿Por qué no?

2. ¿Considera que todavía necesita más práctica en la producción de los sonidos /t/,/d/ y /Id/? ¿Por qué? ¿Por qué no?

3. ¿Cuánto le ayudó esta técnica?
$\square$ mucho
$\square$ bastante $\square$ poco
№ me ayudó.

4. ¿De qué maneras le ayudó esta técnica? Especifique.

1. ¿Considera que esta técnica le ayudará a recordar la pronunciación de /t/,/d/ y /Id/ en su trabajo una vez que el curso de inglés haya finalizado? Especifique. 


$$
\mid
$$




\section{Appendix 4}

Ralph Akinoso is a Nigerian agricultural engineer who works for the Federal Institute of Industrial Research Oshodi. He sent you the information he has collected about the food crisis for you to help him with verbs in passive voice.

\section{Instructions:}

- Individually, transform sentences into the passive voice and decide if it is necessary to keep the agent (by ) in your sentences. If not, eliminate it.

- When you finish, read the passive voice sentences you transformed to your partner. He/she is going to confirm if they are correct or not. Then, listen to your partner's passive voice sentences and give him/her feedback.

\begin{tabular}{|lc|}
\hline & Useful expressions: \\
-It's your/mine turn. & - Is my sentence correct? \\
-Can you repeat that? & -No, I think you should check... \\
\hline
\end{tabular}

\section{Student A}

1 According to some critics, governments did not produce enough food to feed people.

2. The results of planting more corn to make ethanol were assessed.

3. Experts established the term "agflation" to define the relationship between higher grain prices and higher food prices.

4 Scientists researched the consequences of planting less wheat to discover their impact on dietary habits.

5 High wheat prices were based on the scarcity and demand of the product.

6. The studies on sustainable food security were backed up by FAO.

\section{Student B}

1. According to some critics, enough food was not produced to feed people.

2 Biofuel producers assessed the results of planting more corn to make ethanol.

3. The term "agflation" was established to define the relationship between higher grain prices and higher food prices.

4. The consequences of planting less wheat were researched to discover their impact on dietary habits.

5* Some traders based high wheat prices on the scarcity and demand of the product.

6. FAO backed up the studies on sustainable food security. 


\section{Appendix 5}

Working with $-(e)$ d endings!

fo After the teacher's signal, write a verb whose -(e)d ending is pronounced as / $d /$ as quickly as you can.

fo Then, pass the handout to the classmate on your right. He/she must write a different verb.

fo The group that has the most verbs is the winner.

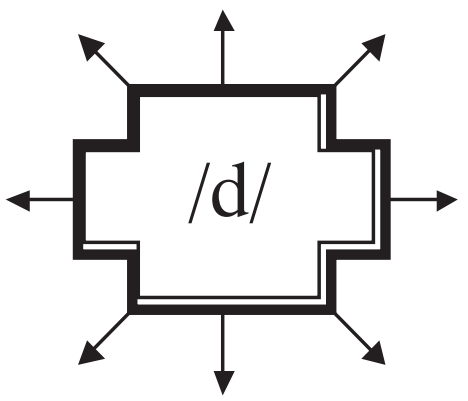

\section{Appendix 6}

Identifying $/ \mathrm{d} /$

Read the following method section of a research article and circle verb forms ending in -(e)d pronounced as $/ \mathrm{Id} /$.

The study was descriptive and primarily included data collected from small-scale farmers/households, large-scale farms, millers, NGOs and government storage facilities. Three instruments, a questionnaire, interview schedule and observation form were used in the collection of primary data. The instruments were validated for face and contents by specialists in this area. They were further pre-tested at the Ngwempisi RDA by interviewing farmers who did not form part of the final respondents.

Since the main thrust of the research was storage structures, it was considered necessary that whoever was to be interviewed must own and use crop storage structures. The respondents selected were operators of government storage facilities, large and small-scale millers, large-scale farms, and the small-scale farmers/households. Arising from the observations made on maize tanks during the field work, the study was extended to include visits to artisans who fabricate the metal tanks. These were spread all over the country and many of them were visited. The data were analyzed quantitatively and qualitatively using the Statistical Package for the Social Sciences (SPSS) version 10.0. The SPSS contributed to derive statistics of frequencies and percentages. The results were presented in tables and charts. 


\section{Appendix 7}

You attended a conference on the global food crisis at UCR's main campus. You took notes on the main points of the conference; however, you missed some verb forms in your information.

\section{Instructions $\theta$}

1. Ask your partner questions to complete the following chart with verb forms ending in -(e)d.

2. Pay attention to the pronunciation of -(e)d endings.

3. When you finish, check the answers with your partner.

\section{Student A}

1

\begin{tabular}{|c|c|c|}
\hline & $\begin{array}{c}\text { From } 1974 \text { to } 2005 \text { food prices } \\
\text { by } 75 \% \text {. }\end{array}$ & $\begin{array}{l}\text { Maize prices almost tripled } \\
\text { in the past decade. }\end{array}$ \\
\hline 3 & $\begin{array}{l}\text { Since corn is commonly used } \\
\text { to feed livestock, higher corn } \\
\text { prices lead to higher prices in } \\
\text { animal source foods }\end{array}$ & $\begin{array}{l}\text { Biofuels from grains have } \\
\text { raised food prices between } 70 \\
\text { to } 75 \text { percent. }\end{array}$ \\
\hline $\mathrm{C}$ & $\begin{array}{l}\text { The food crisis } \\
\text { riots in parts } \\
\text { of Africa and Southeast Asia. }\end{array}$ & $\begin{array}{l}\text { The United Nations World } \\
\text { Food Program warned that } \\
\text { North Korea is also facing a } \\
\text { food crisis. }\end{array}$ \\
\hline & $\begin{array}{l}\text { The rising cost of food caused } \\
\text { riots in a number of countries } \\
\text { in recent weeks. }\end{array}$ & $\begin{array}{l}\text { High food prices } \\
\text { poverty in some countries. }\end{array}$ \\
\hline
\end{tabular}

3

The increase in grain prices in fats and oil prices in 2006. The price of rice to near historic levels. Governments were asked to avoid trade restrictions that might increase the crisis.

Demand for rice

levels in many countries.

\section{$\underline{\text { Student B }}$}

\begin{tabular}{|c|c|c|c|}
\hline A & $\begin{array}{l}\text { From } 1974 \text { to } 2005 \text { food prices } \\
\text { dropped by } 75 \% \text {. }\end{array}$ & $\begin{array}{l}\text { Maize prices almost } \\
\text { in the past } \\
\text { decade. }\end{array}$ & $\begin{array}{l}\text { The increase in grain prices } \\
\text { was followed by increases in } \\
\text { fats and oil prices in } 2006 \text {. }\end{array}$ \\
\hline B & $\begin{array}{l}\text { Since corn is commonly } \\
\text { to feed } \\
\text { livestock, higher corn prices } \\
\text { lead to higher prices in animal } \\
\text { source foods }\end{array}$ & $\begin{array}{l}\text { Biofuels from grains } \\
\text { food prices } \\
\text { between } 70 \text { to } 75 \text { percent. }\end{array}$ & $\begin{array}{l}\text { The price of rice has soared to } \\
\text { near historic levels. }\end{array}$ \\
\hline $\mathrm{C}$ & $\begin{array}{l}\text { The food crisis caused riots in } \\
\text { parts of Africa and Southeast } \\
\text { Asia. }\end{array}$ & $\begin{array}{l}\text { The United Nations World } \\
\text { Food Program } \\
\text { that North } \\
\begin{array}{l}\text { Korea is also facing a food } \\
\text { crisis. }\end{array}\end{array}$ & $\begin{array}{l}\text { Governments } \\
\text { to avoid trade restrictions that } \\
\text { might increase the crisis. }\end{array}$ \\
\hline D & $\begin{array}{l}\text { The rising cost of food } \\
\text { riots in a } \\
\text { number of countries in recent } \\
\text { weeks. }\end{array}$ & $\begin{array}{l}\text { High food prices have } \\
\text { increased hunger and } \\
\text { poverty in some countries. }\end{array}$ & $\begin{array}{l}\text { Demand for rice has reached } \\
\text { incredible levels in many } \\
\text { countries. }\end{array}$ \\
\hline
\end{tabular}


